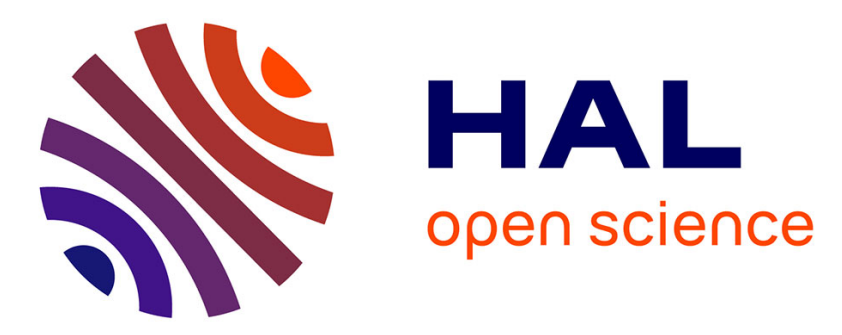

\title{
New data on the Dyrosauridae (Crocodylomorpha) from the Paleocene of Togo
}

Yawovi Zikpi, Guillaume Guinot, Lionel Hautier, Koffi Evenyon Kassegne, Nils Chabrol, Anne-Lise Charruault, Ampah Kodjo C. Johnson, Raphaël Sarr, Pauline Yawoa D. da Costa, Jérémy Martin

\section{To cite this version:}

Yawovi Zikpi, Guillaume Guinot, Lionel Hautier, Koffi Evenyon Kassegne, Nils Chabrol, et al.. New data on the Dyrosauridae (Crocodylomorpha) from the Paleocene of Togo. Annales de Paléontologie, 2021, 107 (2), pp.102472. 10.1016/j.annpal.2021.102472 . hal-03357751

\section{HAL Id: hal-03357751 \\ https://hal.science/hal-03357751}

Submitted on 29 Sep 2021

HAL is a multi-disciplinary open access archive for the deposit and dissemination of scientific research documents, whether they are published or not. The documents may come from teaching and research institutions in France or abroad, or from public or private research centers.
L'archive ouverte pluridisciplinaire HAL, est destinée au dépôt et à la diffusion de documents scientifiques de niveau recherche, publiés ou non, émanant des établissements d'enseignement et de recherche français ou étrangers, des laboratoires publics ou privés. 
New data on the Dyrosauridae (Crocodylomorpha) from the Paleocene of Togo

Nouvelles données sur les Dyrosauridae (Crocodylomorpha) du Paléocène du Togo

Yawovi Zikpi Amoudji ${ }^{1}$, Guillaume Guinot ${ }^{2}$, Lionel Hautier ${ }^{2}, K_{\text {Koffi Evenyon Kassegne }}{ }^{1}$, Nils

Chabrol $^{3}$, Anne-Lise Charruault ${ }^{2}$, Ampah Kodjo C. Johnson ${ }^{1}$, Raphaël Sarr ${ }^{4}$, Pauline Yawoa D.

Da Costa ${ }^{1}$, Jeremy E. Martin*3

1- Département de Géologie, Faculté des Sciences, Université de Lomé, B.P.1515 Lomé, Togo

2- Institut des Sciences de l'Evolution de Montpellier (ISE-M, UMR 5554,

CNRS/UM/IRD/EPHE), Université de Montpellier, 34095 Montpellier Cedex 5, France

3- Univ Lyon, Univ Lyon 1, ENSL, CNRS, LGL-TPE, F-69622, Villeurbanne, France

4- Laboratoire de Sédimentologie et Biostratigraphie, Département de Géologie, Université

Cheikh Anta Diop de Dakar, Sénégal

\title{
*Corresponding author: jeremy.martin@ens-lyon.fr
}

\begin{abstract}
Following our fieldwork in Paleogene deposits of Togo, we herein report cranial as well as postcranial elements belonging to the family Dyrosauridae. This assemblage is dated to the Late Paleocene (Thanetian) from two quarries in southern Togo. The specimens include a partial skull presenting two large supratemporal fossae and a massive occipital condyle; long and slender isolated teeth; amphicoelous vertebrae including several articulated ones; and two osteoderms
\end{abstract}


devoid of carina. The morphology of the partial skull reveals similarities with some African longirostrine forms such as Rhabdognathus spp., although this attribution cannot be confirmed. Longirostrine forms, known in the late Paleocene and early Eocene of the Iullemmeden basin (Nigeria, Niger, Mali, Algeria) and in the phosphates of Morocco and Tunisia, is only represented in Thanetian levels in Togo. Different palaeoenvironmental settings seem to have characterized the various African basins during the lower Eocene, with consequences for the geographic distribution of dyrosaurids. These dyrosaurid remains confirm the presence of the family in Togo during the Paleocene and underline the fossiliferous potential of the coastal sedimentary basin in Togo and in the bay of Benin.

\section{Résumé}

Suite à nos travaux de terrain dans les dépôts du Paléogène du Togo, nous rapportons des éléments crâniens et post-crâniens appartenant à la famille des Dyrosauridae. Cet assemblage de crocodiliens est daté du Paléocène supérieur (Thanétien) affleurant dans deux carrières au Sud du Togo. Les spécimens décrits sont représentés par un crâne partiel présentant de grandes fosses supratemporales et un condyle occipital massif ; des dents isolées effilées et cannelées ; des vertèbres amphicoeles dont plusieurs articulées ; et deux ostéodermes dorsaux sans carène. La morphologie des restes crâniens semble similaire à certaines formes africaines longirostres telles que Rhabdognathus spp., bien qu'une telle attribution générique ne puisse être confirmée. Les formes longirostres, connues au Paléocène supérieur et à l'Eocène inférieur dans le bassin des Iullemmeden (Nigéria, Niger, Mali et Algérie), dans les phosphates du Maroc et de Tunisie, ne sont représentées au Togo qu'au Thanétien. Des évolutions paléoenvironnementales différentes semblent avoir caractérisé les divers bassins d'Afrique à l'Eocène inférieur, et ont probablement 
influencé la distribution géographique des Dyrosauridae. Ces restes inédits de Dyrosauridae confirment d'une part la présence de ce groupe au Paléocène au Togo et accentuent d'autre part le potentiel fossilifère du bassin sédimentaire côtier du Togo et des dépôts contemporains de la baie du Bénin.

Key-words: Crocodylomorpha; Dyrosauridae; Comparative anatomy; Stratigraphy; Paleoenvironment.

Mots-clés: Crocodylomorpha; Dyrosauridae; Anatomie comparée; Stratigraphie; Paléoenvironnement.

\section{Introduction}

Dyrosauridae represent a crocodylomorph family with a large geographic distribution, known mainly from shallow marine paleoenvironments covering the Upper Cretaceous - Eocene interval. This family is remarkable for having survived the Cretaceous-Paleogene (K-Pg) mass extinction (Buffetaut, 1982; Jouve 2005; Barbosa et al., 2008; Hill et al., 2008; Hastings et al., 2011; Martin et al., 2014a; Shiller et al, 2016; Martin et al., 2018; Jouve et al., 2020; Jouve and Jalil, 2020). Some members of this family were also recovered from lignite deposits (Hastings et al., 2011), suggesting their capacity to live durably in different aquatic environments, including freshwater (Denton et al., 1997; Jouve et al., 2008b). The Dyrosauridae were erected by De Stefano (1903) and their representatives are known in North America (Troxell, 1925; Denton et al., 1997; Souza et al., 2019), South America (Argollo et al., 1987; Buffetaut, 1991; Carvalho et al., 1997; Gallo et al., 2001; Barbosa et al., 2008; Hastings et al., 2010, 2011, 2014; Jouve et al., 2020), Asia (Buffetaut, 1977; Buffetaut, 1978a; Buffetaut, 1978b; Denton et al., 1997; Jouve et al., 2005b; Storrs, 1986; Rana, 1987; Prasad et Singh, 1991; Khosla et al., 2009), the Middle East 
(Langston, 1995), and possibly in Europe (Buffetaut et Lauverjat, 1978; but see Pérez-García et al., 2020). In Africa, Dyrosauridae have been exclusively recovered from marine phosphate deposits in Morocco (Jouve, 2005; Jouve et al. 2005a, b; Jouve et al. 2006; 2008), Algeria (Thevenin, 1911a; Jouve, 2005), Tunisia (Thevenin, 1911b; Arambourg, 1952; Bergounioux, 1955; Buffetaut, 1978; Moody and Buffetaut, 1981; Jouve, 2005), Egypt (Churcher et Russell, 1992; Lamanna et al., 2004), Sudan (Buffetaut et al., 1990; Salih et al., 2016), Ethiopia (Buffetaut 1982), Kenya (Sertich et al., 2006), Niger, Mali, and Nigeria (Buffetaut, 1979; 1980; Brochu et al., 2002; Jouve, 2007), as well as Senegal (Tessier, 1952; Martin et al., 2018), and Angola (Jouve and Schwarz, 2004). According to Buffetaut (1982) and subsequent studies (e.g. Martin et al., 2018), Jouve et al., 2019), the period spanning the Upper Cretaceous - Paleocene witnessed an increasing diversification of the Dyrosauridae (six genera during the Cretaceous and 11 during the Paleocene). This diversification reached an optimum during the Late Paleocene and might have resulted from the major end Cretaceous biotic disruption when the extinction of large marine predators freed ecological niches for Dyrosauridae (Jouve et al., 2008). The timing of the extinction of Dyrosauridae remains poorly resolved stratigraphically, either during the Ypresian (Buffetaut, 1982; Hill et al., 2008; Martin et al., 2014) or during the Lutetian (Tessier, 1952; Buffetaut, 1978a, b), and the reasons for their extinction is uncertain.

Dyrosauridae were first mentioned in the coastal sedimentary basin of Togo by Stromer (1910) from the then exploited limestones at Adabion. These now abandoned quarries were located close to currently exploited WACEM and SCAN-TOGO quarries that we prospected in 2016, 2017, 2018 and 2019 (Fig. 1A). Stromer (1910) did illustrate a vertebra that he attributed to cf. Dyrosaurus, at that time considered as belonging to the family Champsosauridae. In this area, Togolese outcrops cover the Paleocene and early Eocene (Johnson et al., 2000; Da Costa et al., 
2013) and include detrital and carbonate sequences preserving a rich vertebrate fauna (Stromer, 1910; Guinot et al., 2020). With the exception of the works of Stromer (1910) and the recent work of Guinot et al. (2020) on elasmobranch assemblages from the upper levels of this sedimentary succession, studies on vertebrates from this formation remain scarce. Stromer (1910: p. 479) indicates that "The fossils are in a sliver-hard yellow limestone filled with fragments of conchylia and many stone cores of very small snails and small crustacean claws, but apparently no larger foraminifera or calcareous algae". Moreover, according to Guinot et al. (2020), the levels that produced Stromer's (1910) dyrosaurid vertebra are the stratigraphic equivalents of the levels presented here. In the present contribution, several Dyrosauridae specimens discovered in quarries around the city of Tabligbo are described and their importance for the fossil record of the group in Africa is discussed.

\section{Geological and geographical settings}

The studied sedimentological sections are located in the quarries of WACEM and SCAN-TOGO, at 6 and $8 \mathrm{~km}$ to the northeast of the city of Tabligbo, respectively (Fig. 1) in the Maritime region (South Togo). This region belongs to the Togolese coastal sedimentary basin where three main successions have been recognized (Johnson et al., 2020): the Tabligbo Group, the HahotoéKpogamé phosphatic complex and the Upper detrital series. The Tabligbo Group, under study here, is composed at its base of upper Cretaceous deposits (Campanian-Maastrichtian) that cover the panafrican basement of the Dahomeyides and that is characterized by detrital facies (Monciardini et al., 1986; Da Costa et al., 2009; 2013b). These detrital levels are overlain by a set of transgressive Paleocene deposits characterized by carbonates (Slansky, 1962; Monciardini et al., 1986; Johnson et al., 2000; 2008; Da Costa et al., 2013a, b, c). The stratigraphic series ends with a set of marls and laminated claystones (palygorskite) from the base of the Eocene. 
Biostratigraphic and paleoenvironmental studies conducted on the Tabligbo Group are essentially framed using foraminifer biozonation (Johnson, 1987; Da Costa et al., 2013) as well as ostracod ecozonation (Damote, 1982; Carbonnel et al., 1989). The top of the detrital formation of the Tabligbo Group shows two facies (Fig. 1C). The basalmost facies includes greyish to yellowish silty sands with a horizontal layering overlain by a second facies that consists of a level of oxidized sands with a varying thickness between 30 and $40 \mathrm{~cm}$. These oxidized sands are underlined by a duricrust (about $5 \mathrm{~cm}$ thick) without bioclasts, capped by another duricrust rich in lamellibranch and gastropod bioclasts. The upper duricrust marks the boundary with the Paleocene limestones. In the WACEM quarry, at the base of the Tabligbo limestones, Johnson (1987) reported azoic silty sands with a horizontal layering that he considered to belong to the lower Paleocene, as previously proposed by Slansky (1959) and Monciardini (1972). A similar formation was described by Da Costa (2005) from two wells containing rare benthic foraminifers suggestive of a lower Paleocene age (Danian) for these sands. The presence of oxidized sands near the top of the siltites has never been mentioned in the literature and seems to be limited laterally. However, the presence of a paleosurface at the base of the limestones (Johnson, 1987) agrees with the presence of a paleosoil recovered at the top of the detrital formation. The lower part of the Paleocene carbonate formation starts with a compact limestone of about $40 \mathrm{~cm}$ thick possessing rare quartz grains and rich in bioclasts. Above this level sits a nodular limestone, sometime weathered, of brittle consistence and containing shells. The carbonate facies is topped by a level containing abundant and tiny echinoderms (Togocyamus limestones). The upper part of the formation, with a thickness varying between 2 and $2.5 \mathrm{~m}$ is made of a compact limestone rich in oysters and nautiles, overlain by a glauconitic facies (Fig. 1C). The entire carbonate series has yielded a microfauna with planktonic foraminifers, characterizing the P3-P5 biozone (Monciardini et al., 1986; Johnson, 1987; Johnson et al., 2000; Da Costa, 2005; Da Costa et al., 
2013a; 2013b; 2013c). Additional samplings made from the lower limestone unit (nodular and Togocyamus limestones) during recent field campaigns yielded a weakly diverse planktonic foraminiferal assemblage including Morozovella aequa (Cushman \& Renz, 1942) (zones P4c to E5) and Morozovella acuta (Toulmin, 1941) (zones P4b to E2). The benthic foraminiferal fauna includes Rotalia guinezonensis Lys, 1961 [upper Paleocene of Ivory Coast (Lys, 1961), Nigeria (Kogbe, 1981)] as well as Nummulitoides tessieri (Abrard, 1956) and Valvulineria tessieri Lys, 1961 [upper Paleocene and lower Eocene of Western Africa (Kogbe et al., 1986; Tokpa, 1997)]. The ostracod fauna comprises Leguminocythereis exigua Apostolescu, 1961, Cytherella sylvesterbradleyi Reyment, 1963, Paracypris africana Sarr, 1998, Soudanella laciniosa laciniosa Apostolescu, 1961 and Buntonia fortunata Apostolescu, 1961. This association is characteristic of the upper Paleocene of Senegal basin (Carbonnel, 1986; Sarr, 2000, 2015), and is known from the Gulf of Guinea (Côte d'Ivoire, Benin, Nigeria), North Africa and Trans-Saharian basins (Sarr, 2000, 2013; Elewa, 2002; Carbonnel \& Johnson, 1989; Damotte \& Fleury, 1987; Morsi et al., 2011). This ostracod and foraminiferal association, accompanied by an elasmobranch fauna found at the top of the oxidized sands and in the lower limestone unit (GG. pers. obs.) that shares many species (Squatiscyllium nigeriensis, 'Raja' louisi, Atlantitrygon sudrei, Coupatezia russelli, 'Myliobatis' nzadinensis) with the Thanetian assemblage of Nigeria (Cappetta, 1972), all suggest a Thanetian age for the crocodylomorph specimens described here.

\section{Material and methods}

The herein described specimens have been collected from the oxidized sands and from the base of the carbonate level from two different quarries distant by about $5 \mathrm{~km}$ (Fig. 1B). A set of articulated vertebrae associated with rib fragments (Fig. 1E) was discovered South of the SCANTOGO quarry (coordinates: N06³6'26,9”; E001³4'11,6”) in February 2019; they come from 
the boundary between the oxidized sands and limestones. Various isolated postcranial elements, including several vertebrae and teeth as well as two osteoderms were also recovered during surface prospections (November 2019) at the top of the sandy level of the WACEM quarry (coordinates: N06³'05.2”; E001³1'31.7’'). However, those fossils are partly encased in limestone, suggesting a similar stratigraphic provenance as the articulated vertebrae recovered from SCAN-TOGO. Some specimens are encrusted by gastropod and bivalve shells. The posterior part of the skull (Figs. 1D, 2) was discovered in June 2018, North of the SCAN-TOGO quarry (coordinates: N06³6’28,9”; E001³4'07,0”). Although this specimen was discovered near the top of the oxidized sands, its precise stratigraphic origin within the oxidized sands or within the boundary with the overlying limestone is difficult to confirm due to the mining activity, which remodeled the prospected surfaces.

All figured and unfigured specimens are currently stored in the collections of the University of Montpellier for preparation and study, and will be housed in the collections of the Département de Géologie de l'Université de Lomé. Official specimen numbers are preceded by 'ULDG TAB8', shorten here to 'TAB8'.

\section{Systématique}

Crocodylomorpha Hay, 1930

Dyrosauridae De Stefano, 1903

Dyrosauridae indet.

Figs 2-7, Tab. 1 
Material: TAB8-1, posterior part of a skull (ScanTogo); TAB8-2, an isolated tooth (WACEM); TAB8-3 a set of vertebrae from a single individual and comprising vertebrae dorsal\#9 to caudal\#1 (SCAN-TOGO); TAB8-4, a calcaneum (WACEM); a single individual with two dorsal vertebrae (TAB8-5 and TAB8-6) and two cervical vertebrae (TAB8-7 and TAB8-8) (WACEM); TAB8-9, a posterior dorsal vertebra (WACEM); TAB8-10, a caudal vertebra (WACEM); TAB811 and TAB8-12, two osteoderms.

Locality and horizon: Oxidized sands and boundary between oxidized sands and limestones, WACEM and SCAN-TOGO quarries, Tabligbo, Togo, Thanetian.

\section{Description:}

Skull. The skull (Fig. 2) is heavily damaged and only preserves the base of the skull table including the occipital condyle, a portion of the palate as well as the left branch of the quadrate. The occipital surface of the skull shows a well-developed occipital condyle. In dorsal or ventral view, the lower temporal fenestra is partially visible, as evidenced by its posterior margin composed of elements of the quadrate and quadratojugal; its anterior limit is less clear and is underlined by the position of the torus transiliens of the pterygoid. The left anteromedial margin of the supratemporal fenestra is preserved as a fragment of frontal bone (Fig. 2A). A portion of the postorbital seems preserved, marking anteriorly the contour of the supratemporal fenestra. The lateral portion of the skull table appears to preserve the rod-like postorbital-squamosal bar, which is crushed and collapsed in a lateral direction against the anterior portion of the jugal (Fig. 2A). Here, the postorbital-squamosal suture cannot be identified. The sagittal (or interfenestral) bar of the skull table is comprised of the frontal and parietal and is here partially preserved through a longitudinal section (poorly preserved indentation indicates that the fronto-parietal suture is preserved in the anterior third of the interfenestral bar); its extension, together with the 
general positions of the squamosal and postorbital, indicates that the skull table is longer than wide. Here, a tentative reconstruction of the skull table presents a supratemporal length of $16 \mathrm{~cm}$ and a maximum width of $6 \mathrm{~cm}$. The exoccipital forms the main part of the occipital surface. Its dorsal surface is swollen and corresponds to an extensive area that participates anteriorly into the otic region. In dorsal view, the exoccipital projects further posteriorly than the occipital condyle. The basioccipital is relatively well preserved but because of dorsoventral crushing, the sutures between the basioccipital and exoccipital cannot be identified. The basioccipital includes a massive occipital condyle, larger than high $(5.8 \mathrm{by} 3 \mathrm{~cm})$. At the base of the occipital condyle, the basioccipital supports two well-marked vascular foramina (about $0.2 \mathrm{~cm}$ in diameter) and is flanked by a vertical channel (Fig. 2C). The basioccipital is well extended ventrally, possesses a constriction in its middle portion, is lightly splayed in posterior view but its ventral processes are not preserved and the median Eustachian foramen is not preserved. A pair of large openings correspond to the lateral Eustachian foramina and are positioned in a dorsal position along the anterior wall of the basioccipital (Fig. 2B). The left quadrate is sutured to a quadratojugal fragment as well as a fragment of jugal (Fig. 2A). Although the sutural contacts can be roughly identified, bone erosion and sediment infilling render the precise sutural path difficult to follow. Here, the posterior extent of the jugal is visible, covering the dorsolateral surface of the quadratojugal as a longitudinal bulge laterally and as a thin plate medially. It does not participate into the lower temporal fenestra, allowing the quadratojugal to be visible in dorsal view along the lateral border of the lower temporal fenestra. As observed in dorsal view, the quadratojugal makes the posterior margin of the lower temporal fenestra. Although broken, the anteromedial process of the quadratojugal preserves a sutural surface on top of the dorsal surface of the quadrate, indicating that the quadratojugal was running along the posteromedial border of the lower temporal fenestra, thus excluding the quadrate from participating in the latter. The 
quadratojugal is preserved completely until its posteriormost tip and contributes, with the lateral quadrate hemicondyle in the lateral portion of the jaw joint. In ventral and occipital views, the quadrate is marked in its medial margin by a long furrow along the suture with the exoccipital, corresponding to the cranioquadrate groove (Fig. 2B, C). This groove does not open laterally nor dorsally, and is completely included within the exoccipital and quadrate. The opening of the cranioquadrate groove in the otic passage is not preserved. The quadrate condyles are slightly eroded; there is no clear individualization of a medial and lateral hemicondyles. The ventral surface of the quadrate bears a faint eroded crest that runs longitudinally to the quadratojugal suture for most of the length of the quadrate branch.

Dentition: Tooth crown fragments are common in the deposits. A single relatively large and wellpreserved tooth crown was recovered at WACEM quarry. Its length is $2.3 \mathrm{~cm}$ and its width at the base of the crown is $0.8 \mathrm{~cm}$. The crown is tapering with a sigmoid shape (Fig. 3). The thin enamel bears thin apicobasal ridges on both the lingual and labial surfaces that are difficult to distinguish from the mesiodistal carinae, which are present as indicated by the white arrow in Figure 3.

Postcranial skeleton: Postcranial remains discovered in the two quarries comprise vertebrae, a calcaneum and two osteoderms. Most vertebrae have only their centrum preserved, sometimes with the base of the transverse processes or of the neural arch. All vertebral centra are weakly amphicoelous (average centrum length $=56 \mathrm{~mm}$; Table 1). The vertebrae discovered in the SCAN-TOGO quarry all belong to a single individual (Figs. 1E, 3); those from WACEM quarry were surface-collected and most probably represent several individuals. Vertebrae were numbered following morphological features observed in articulated specimens (e.g. Schwarz et al., 2006; Jouve et al. 2006; Martin et al. 2018). 
From WACEM quarry, a single cervical vertebra (TAB8-7) comes from the anterior part of the cervical series. This corresponds to a weathered specimen, especially its dorsal surface, which preserves only the base of the neural arch and is encrusted with invertebrate shells (Fig. 6). The centrum is amphicoelous and carries on its lateral surfaces the distinctly separated diapophyses and parapophyses. Parapophyses emerge from the lower part of the lateral surface of the vertebral body and project anteroventrally. Diapophyses, as parapophyses, are placed along the anterior margin of the centrum. The hypapophysis is broken off but its proximal region is preserved and originates in the first half of the centrum; the second half of the centrum is made of a ridge that stretches along the entire ventral surface.

A set of vertebrae discovered in the SCAN-TOGO quarry belongs to a single individual (see field photo in Fig. 1E) and preserves a connection in the posteriormost vertebral region including the sacral series (Fig. 4A, B). This partially articulated specimen comprises scattered vertebrae from the anterior part of the thoracal series (Fig. 5B), connected thoracal vertebrae \#9 to \#15 (Fig. 5A, 5D-F), the first sacral vertebra and its right sacral rib, the right sacral rib of the second sacral vertebra (Fig. 5G-J), the first caudal vertebra (Fig. 5K, L) as well as caudal vertebrae from the posterior series found scattered around (Fig. 5M-O). Six thoracal and three caudal vertebrae were recovered close-by in isolation and likely belong to the same individual. In the articulated column, all centra are about as long as high; they are slightly longer, wider, and decrease in height toward the posterior end of the thoracal series; the most anteriorly preserved dorsal centra are slightly wider on their anterior articular surface than on their posterior surface (Table 1). In ventral view, the centrum is hourglass-shaped (Fig. 5D). Its ventral surface is concave as seen in lateral view (Fig. 5E). From the same view, the lower corner of the anterior margin is slightly higher than the posterior lower corner. In all thoracal vertebrae of the 
articulated series, a well-defined shallow fossa is visible underneath the transverse process (Fig. $5 \mathrm{E})$. The transverse process of vertebra $\# 9$, although sectioned, shows that it is slightly inclined anteriorly (Fig. 5A) whereas the transverse process of vertebra $\# 12$ is horizontal. Prezygapophyses for all these thoracal vertebrae are oriented dorsally and are nearly aligned with the anterior margin of the centrum. The articular surface of the prezygapophyses is inclined medially (Fig. 5B, F) at about $45^{\circ}-50^{\circ}$. Neural spines are broken but their proximal parts cover a little less than the centrum length. A short hypapophysis is present in one thoracal vertebra found scattered around the skeleton (Fig. 5B, C). All other vertebrae from the thoracal series preserving connection (i.e. from the \#9 backward) do not possess hypapophyses. Postzygapophyses are thick and dorsally frame a small channel located in the continuity of the neural spine. The anterior limit of the prezygapophyses slightly goes past the anterior level of the centrum. The first sacral vertebra preserves a complete centrum, a damaged neural arch, the right sacral rib which is detached from the centrum and still embedded in the sediment (Fig. 5G, H, J). The centrum of the first sacral vertebra is wider than tall. Although partly hidden by sediment, the articular surface of the sacral rib covers the anterior two-thirds of the centrum length. On this centrum, there is no suture for reception of the second sacral rib. The anterior process of the first sacral rib has a distinct anterolateral projection (Fig. 5G, H). The second sacral rib is fragmentary and its posterior process is broken off. The centrum of caudal vertebra \#1 is longer and wider than high; it is characterized by an absence of articular surface for the insertion of the haemal arches on its ventral surface. The neural arch is partially preserved and the prezygapophysis projects distinctly in front of the centrum. The left transverse process is preserved, slightly inclined posteriorly and is about as long as the centrum width. Other caudal vertebrae from more posterior positions recovered at SCAN-TOGO from the single individual and as isolated specimens from WACEM quarry (Fig. 5C, D) are characterized by the presence of transverse processes on the centrum. The 
articular surfaces of the centra are rectangular; the ventral surface is strongly concave as observed in lateral view. On their ventral surface, they all present an anteroposterior furrow spreading along the entire surface (Fig. $4 \mathrm{~N}$ ). They also possess prominent facets on the anterior and posterior corners of the centra for accommodating the haemal arches.

A left calcaneum was found isolated as part of a limestone block from WACEM quarry and was acid-prepared (Fig. 6). It is distinctly large with an anteroposterior length of $8 \mathrm{~cm}$ and is nearly complete, except the medial ridge of the posterior tuber, which is broken off. The calcaneum possesses a strong medial process, located just posterior to a deep calcaneal socket that accommodates the astragalar peg. The anterior ball is longer than wide and shows a flat foot pierced by a $1 \mathrm{~cm}$ wide depression in its posterior area. Ventrally, the foot of the anterior calcaneal ball is separated from the posterior tuber by the deep lateroventral channel. This channel is delimited medially by a thick bony wall; on its lateral side, the channel merges with the lateral body of the calcaneum. The posterior tuber makes about twice the height of the anterior ball. The articular surface of the posterior tuber hosts a dorsoventral sulcus that separates a medial ridge from a lateral ridge. Here, a $6 \mathrm{~mm}$ wide foramen opens in the ventral half of the lateral ridge.

Two isolated osteoderms (Fig. 7E, F) were discovered at WACEM quarry. They are rectangular in shape and do not present imbricating sutures. All osteoderms lack an external keel on their outer surface. The dorsal surface is strongly vaulted and ornamented with numerous rounded, wide and deep pits about $2 \mathrm{~mm}$ in width. These pits are distributed radially and are clearly separated from each other. Pits in TAB8-11 are larger than in osteoderms TAB8-12. These osteoderms have rounded edges; their anterior margin is slightly narrower than the posterior margin. Osteoderm TAB8-11 (Fig. 7E) shows an anterolateral process devoid of 
ornamentation. The anterior margin is smooth and corresponds to the articular surface that fits beneath the anteriorly placed osteoderms in the dorsal series.

\section{Comparison and identification of the Togolese material}

Among the Togolese discoveries presented in this work, the posterior half of a cranium is certainly the most characteristic one. This specimen possesses a combination of characters that are diagnostic of the family Dyrosauridae, including the presence of paroccipital processes that project posteriorly, beyond the level of the occipital condyle; a massive and robust occipital condyle; a sagittal bar of the skull table that is distinctly elongate and thin, and comprised of twothird of the frontal and one-third of the parietal, as well as a rod like temporal bar consisting of the postorbital and squamosal, indicating that the supratemporal fenestrae are at least twice longer than wide and cover most of the dorsal surface of the skull table; lateral Eustachian openings that open in a dorsal position; a quadratojugal that participates in the jaw joint and completely encloses the posterior and medial margins of the lower temporal fenestra. These characters uphold an attribution of this specimen to the family Dyrosauridae (Buffetaut 1976; Buffetaut, 1982; Brochu et al., 2002; Jouve et Schwarz, 2004; Jouve 2005; Jouve et al., 2005a; Barbosa et al., 2008; Hastings et al., 2010, 2011, 2015). Because of the fragmentary nature of this

cranial material, a generic attribution is difficult to propose but a comparison with previously described complete skulls allows some clarifications. The supratemporal fenestra of the Togolese specimen is distinctly longer than that of Anthracosuchus balrogus (Hastings et al., 2015) or Cerrejonisuchus improcerus (Hastings et al. 2011). However, the dimensions of the supratemporal fenestrae in the Togolese specimen recall those in Rhabdognathus (Brochu et al., 2002; Jouve et al., 2007) even if its fragmentary nature does not allow distinguishing the 
Togolese specimen from other genera such as Dyrosaurus, Arambourgisuchus, Hyposaurus or Guarinisuchus. The supratemporal width to length ratio measured in the Togolese specimen is smaller than $0.4(0.38)$. This ratio is comparable with that of Guarinisuchus munizi (Barbosa et al., 2008), Rhabdognathus rarus (Buffetaut, 1980) and Rhabdognathus sp. (Brochu et al., 2002), which all possess distinctly elongate supratemporal fenestrae. These characteristics indicate similarities between the incomplete Togolese skull and other longirostrine dyrosaurids such as Rhabdognathus keiniensis (Buffetaut, 1980; Jouve et al., 2007), Rhabdognathus sp. (Brochu et al., 2002), Dyrosaurus phosphaticus (Thévenin, 1911; Piveteau, 1935; Jouve, 2005), and Arambourgisuchus khouribgaensis (Jouve et al., 2005). Only the discovery of more complete specimens will refine these identifications.

All vertebrae discovered at both quarries are slightly amphicoelous, excluding an attribution to the Eusuchia, represented by gavialoids and tomistomines from Paleocene and Eocene coastal deposits (see review in Piras et al., 2007 and Jouve et al., 2019). The discovery at the SCAN-TOGO quarry of an axial skeleton (TAB8-3) indicates a single large individual, roughly estimated to have attained a total length of 5 metres (based on a presacral vertebral length of $1500 \mathrm{~mm}$ (Table 1) and on the relative proportion of skeletal elements based on Fig. 1 in Schwarz et al. 2006 or on the complete specimen from Jouve et al., 2006). This partial skeleton (TAB8-3) allows the identification of morphological variation for the thoracal and caudal morphotypes (see Schwarz et al., 2006; Jouve et al. 2006; Martin et al., 2018; Souza et al., 2019 for vertebral morphological variation among dyrosaurids). As such, the absence of hypapophysis is observed from thoracal vertebra \#6 backward in a complete series in D. maghribiensis (Jouve et al., 2006) indicating that the vertebra found scattered with the skeleton from SCAN-TOGO (Fig. 4B, C) most probably belongs to thoracal vertebra anterior to vertebra \#6. The inclined 
transverse process of thoracal vertebra \#9 is similar to that of thoracal vertebra \#10 of $D$. maghribiensis (Jouve et al., 2006). Conversely, the transverse process of thoracal vertebra \#12 shows a horizontal transverse process, confirming that this morphology is typical of more posterior thoracal vertebrae, although other completely articulated skeletons would be needed to assess vertebral morphological variability. In addition, the presence of shallow fossae is similar to what has been reported in thoracal vertebrae of the posterior region in Dyrosaurus and Congosaurus (Schwarz et al. 2006) but also in a Danian dyrosaurid from Senegal (Martin et al. 2018). The calcaneum described above from WACEM quarry is similar in many ways to another left calcaneum described with the partial dyrosaurid skeleton from the Danian of Senegal (Martin et al. 2018). There is no sutural overlap of the second sacral rib on the first caudal centrum in the Togolese dyrosaurid, a condition similar to Dyrosaurus sp. (Schwarz et al. 2006) and to the Senegalese dyrosaurid (Martin et al., 2018), as opposed to Rhabdognathus sp. (Langston, 1995). Calcanea are rarely described in dyrosaurids (Langston, 1995) and this one differs from the Senegalese specimen in possessing a deep lateroventral channel, an anterior ball slightly longer than high and by displaying large vascularization openings (e.g. on the ventral surface of the foot, Fig. 5F). Following Buffetaut (1976), Schwarz et al. (2006), Jouve et al. (2006) and Martin et al. (2018), Dyrosauridae possess a combination of postcranial characters that are positively observed among the specimens discovered from both Togolese quarries. As such, they include slightly amphicoelous vertebral centra; mediolaterally compressed caudal vertebrae possessing rectangular articular surfaces of the centra and wide chevron facets and ornamented, flat, subrectangular dorsal osteoderms. All these characters are observed in the Togolese specimens, supporting their attribution to the Dyrosauridae. 
The partial skull from SCAN-TOGO was discovered $200 \mathrm{~m}$ away from the articulated vertebrae and although the specimens come from the oxidized sands or close to the limit with the overlying limestones (see Material and methods), it is most probable that they do not belong to the same individual. Although fragmentary, most of the isolated vertebrae discovered at WACEM quarry are similar in morphology and confirm the presence of dyrosaurids being represented by different size classes, reminiscent of different species and/or different ontogenetic stages. Vertebra TAB8-9 (Fig. 7A, B) corresponds to a thoracal vertebra of the middle portion of the column, probably anterior to thoracal position $\# 9$, which displays a distinctive small size in comparison to the large cervical vertebra recovered close-by (Fig. 6). Its small dimensions in comparison to other vertebrae from the thoracal series might be suggestive of the presence of a smaller dyrosaurid in the assemblage, either belonging to a separate species, or to a different ontogenetic stage of the same species. However, it is currently impossible to ascertain the presence of several dyrosaurid species in the Tabligbo Group based on the morphology of vertebrae alone.

\section{Paleoenvironment}

Dyrosaurid possess a wide spectrum of environmental tolerance. Although most of their remains have been recovered from shallow water marine deposits (see discussion in Buffetaut, 1982), some were also identified in freshwater deposits (Buffetaut, 1978a, 1978b; Rana, 1987; Buffetaut, 1990; Prasad and Singh, 1991; Sertich et al., 2006; Hastings and Bloch, 2007; Khosla et al., 2009). The Togolese specimens come from the base of the limestone level, contacting the detrital basal unit (boundary between oxidized sands and the limestone). These limestones were deposited in a shallow marine environment or a lagoon (coastal) containing a rich benthic fauna (Johnson et al., 2000; Da Costa, 2005). This abundance of benthic invertebrate specimens 
concurs with bioclast diversity (gastropods, bivalves, brachiopods) and the abundance of wellpreserved oyster shells attached to some bone remains. This depositional setting is also confirmed by the composition of the elasmobranch fauna (Squatiscyllium nigeriensis, 'Raja' louisi, Atlantitrygon sudrei, Coupatezia russelli, 'Myliobatis' nzadinensis) retrieved around the vertebrate specimens (GG, pers. obs.) including species that are fully marine/lagoonal. The state of preservation of the articulated vertebral column from SCAN-TOGO quarry suggests a short transportation event and a moderate post-depositional perturbation of the carcass (Syme and Salisbury, 2014). The animal, after a death in shallow waters, was probably lying at a depth below the base of the surf zone for some prolonged time where some of the exposed bones provided a substrate for invertebrates.

Dyrosauridae from the Tabligbo Group are among the oldest fossil vertebrates recovered from a marine deposit in the emerged area of the coastal sedimentary basin of Togo. The marine coastal deposit described in this study is similar to other paleoenvironments from other African basins that yielded Rhabdognathus (Swinton, 1930; Buffetaut, 1980; Brochu et al., 2002; Hill et al., 2008;), Phosphatosaurus (Bergounioux 1954, 1955; Buffetaut 1978; Moody et Buffetaut 1981; Hill et al., 2008), Sokotosuchus (Halstead, 1975; Hastings et al., 2011), Tilemsisuchus (Buffetaut, 1979), Dyrosaurus (Thomas, 1893; Jouve et al., 2005), Congosaurus (Arambourg, 1952; Buffetaut, 1976), Arambourgisuchus (Jouve et al., 2005b), Atlantosuchus (Jouve et al., 2008), and Chenanisuchus (Jouve et al., 2005a). The presence of Dyrosauridae in a shallow marine environment in Togo is therefore in good agreement with data from the literature and confirms that Dyrosauridae occupied successfully the marine coastal environments of Africa during the Paleocene.

\section{Dyrosaurid distribution in Africa}


Africa hosted the largest diversity of Dyrosauridae during the Paleocene with Congosaurus bequaerti from the Selandian of Cabinda (Arambourg, 1952; Jouve et al., 2004), Rhabdognathus aslerensis from the Maastrichtian or Paleocene of Mali (Brochu, 2002; Jouve, 2007), Chenanisuchus lateroculi, and Arambourgisuchus khouribgaensis from the Thanetian of Morocco (Jouve et al., 2005b); Rhabdognathus keiniensis and Congosaurus compressus from the Paleocene of Mali (Buffetaut, 1980; Jouve 2007), Phosphatosaurus sp. from the Paleocene of Niger and Mali (Buffetaut, 1979), Hyposaurus sp. from the Paleocene of Niger, Nigeria and Mali (Jouve, 2007) and Atlantosuchus coupatezi from the Late Paleocene of Morocco (Jouve et al., 2008). In addition, a number of more fragmentary African specimens have been attributed to Paleocene dyrosaurids (e.g. Jouve, 2007). Thus, in the coastal sedimentary basin of Togo, Stromer (1910) was the first to report on their presence based on a single vertebra. Our recent discoveries gathered a fragmentary assemblage but indicate that dyrosaurid remains are abundant and allow catching a glimpse of their diversity within a constrained framework. Such occurrence is in agreement with a wide distribution of Dyrosauridae along the coastlines of Africa during the Paleocene and Eocene highlighting possible migration routes between biogeographic areas of the Tethys and South and North America (Troxell, 1925; Buffetaut, 1976; Buffetaut, 1978; Buffetaut, 1980; Langston, 1995; Brochu et al., 2002; Jouve et Schwarz, 2004; Jouve, 2005; Jouve et al., 2005a; Jouve et al., 2005b; Jouve et al., 2006; Jouve, 2007; Jouve et al., 2008; Martin et al., 2018; Cidade et al., 2019). The Paleocene period witnessed a diversification event of the Dyrosauridae, possibly due to the release of ecological niches by marine predators such as mosasaurids, which became extinct at the K-Pg event (Jouve et al., 2008). The dyrosaurid Hyposaurus rogersii is present in North America and its fossil record spans the K-Pg boundary into the lower Paleocene according to previous works (Denton et al., 1997; de Souza et al., 2019) 
but a recent study restricts its occurrence to the Danian (Callahan et al., 2015; see also Jouve et al., 2020 for a discussion of North American dyrosaurid taxonomy).

Ypresian dyrosaurids are commonly represented in North Africa and in the Iullemmeden basin. On the other hand, the absence of dyrosaurids in the Ypresian deposits of the coastal sedimentary basin of Togo could be due to changing regional paleoenvironmental conditions derived from the specific geological history of each basin. For example, in the Togolese basin, during the Thanetian, the Tabligbo limestones were deposited under a coastal setting which depth may not have surpassed about $20 \mathrm{~m}$ (Johnson et al., 2000). In this paleoenvironment were living a rich invertebrate fauna (gastropods, lamellibranchs, oysters, cephalopods, echinoderms) and vertebrates (crocodiles, turtles, osteichthyans and chondrichthyans). The largest predators of this environment, the Dyrosauridae, were relying on an abundant source of prey and seem to have coexisted in great numbers with aggressive behavior recorded between dyrosaurid individuals (Buffetaut, 1983; Martin, 2013). The end of the Thanetian marked a deepening of the depositional setting, as represented by glauconitic levels at the top of the carbonate series, further overlain during the Ypresian by laminated palygorskite clays associated with rare or absence of invertebrate faunas. Following Johnson et al. (2000), this deepening could be concomitant with the tectonic collapse of the West-African margin where sedimentation no longer compensates for subsidence. This phenomenon would entail a confining near the bottom of the basin and a break in the production of carbonate deposits, leading to a basin functioning as a close system. In line with this interpretation, the glauconitic content of sands and limestones at the top of the carbonate formation (about $80 \%$ ) is in favor of an environmental change (deepening of the environment) starting at the end of the Paleocene. Guinot et al. (2020) proposed that the underlying limestones, where Stromer's (1910) specimens were collected, very likely correspond to a different 
paleoenvironment than the glauconitic sandstones. Dyrosauridae were aquatic predators, most certainly preying on fish and in the case of large individuals of Phosphatosaurus were possibly preying on hard-shelled organisms such as turtles (Buffetaut, 1978) in shallow marine waters and along the coastline (Buffetaut, 1976; Buffetaut, 1982). In the Togolese sample at hand, the different individuals representing different size classes mat indicate that locally, different dyrosaurids were occupying different niches. It is therefore possible that the more distal paleoenvironments represented by the glauconitic horizons and especially by the Ypresian argillaceous upper series were not appropriate for members of this group and that the possible Eocene Dyrosauridae were restricted in their distribution to the coastal environments that are not represented in the known outcrops of Togo.

So far, no dyrosaurids have ever been mentioned from the different basins of the bay of Benin, notably the coastal basins of Nigeria (Adegoke et al., 1972; Petters et Olsson, 1979; Akaegbobi et al., 2016), Benin (Bio Lokoto et al., 1998; Kaki et al., 2016; Bio Oumarou et al., 2017) and Ghana (Kjemperud et al., 1992) that compare with the age and geological history of the coastal basin of Togo. Nevertheless, the specimens described in this work indicate a strong fossiliferous potential for Paleocene vertebrate remains in these basins from the Atlantic coast of Africa.

\section{Conclusion}

The material described herein confirms the earlier observations of Stromer (1910) that Dyrosauridae are present in upper Paleocene deposits in West Africa. The anatomical study of these specimens allows us to assign these fossils to the family Dyrosauridae, corresponding to the most completely known remains ever recovered in Togo and inviting future prospections. The presence of Dyrosauridae in Togo confirms the large diversity of this family and its wide 
distribution in low and middle latitudes during the Paleocene. The paleoenvironmental data indicate a coastal marine setting that agrees well with known data from other dyrosaurids and confirms that the group successfully occupied coastal waters of the Paleocene of Africa.

\section{Acknowledgements}

We thank E. Goulignac, director of the SCAN-TOGO quarry and M. Prasad, director of the WACEM quarry in Tabligbo as well as their employees for allowing us access and sampling during our fieldwork. This study was partly funded by CNRS (PICS n²29424). We thank the three reviewers, S. Jouve, A. Khosla and L. Souza as well as associate editor R. Vullo for their time and insightful comments that helped improve the quality of this work. JEM thanks C. Salaviale for assistance with the acquisition of laser surface scans. 


\section{References}

Adegoke, O.S., Dessauvagie, T.F.J., Kogbe, C.A., 1972. Radioactive age determination of glauconite from the type locality of the Ewekoro Formation. Conference on African Geology, 1970, Ibadan, 277-280.

Akaegbobi, I.M., Ogungbesan, G.O., 2016. Geochemistry of the paleocene limestones of ewekoro formation, eastern dahomey basin, southwestern nigeria : implication on provenance and depositional conditions. Ife Journal of Science 18, 1-669.

Arambourg, C., 1952. Les vertébrés fossiles des gisements de phosphates (Maroc, Algérie, Tunisie). Notes et mémoires du Service géologique du Maroc 92, 1-372.

Arambourg, C., 1935. Note préliminaire sur les vertébrés fossiles des phosphates du Maroc. Bull. Société Géologique Fr. 5, 413-439.

Argollo, J., Buffetaut, E., Cappetta, H., Fornari, M., Herail, G., Laubacher, G., Sige, B., Vizcarra, G., 1987. Découverte de vertébrés aquatiques présumés Paléocènes dans les Andes septentrionales des Bolivie (Rio Suches, synclinorium de Puntina). Geobios 20, 123-127.

Barbosa, J.A., Kellner, W.A., Viana, M.S.S., 2008. New dyrosaurid crocodylomorph and evidences for faunal turnover at the K-P transition in Brazil. Proceedings of the Royal Society B 275, 1385-1391.

Bergounioux, F.M., 1952. Appendice : Chéloniens fossiles des phosphates de Gafsa, in Arambourg, C., ed., Les vertébrés fossiles des gisements de phosphates (Maroc, Algérie, Tunisie): Notes et Mémoires du Service Géologique du Maroc 92, 377-396.

Bergounioux, F.M., 1955. Les reptiles fossiles des dépôts phosphatés sud tunisiens. Annales des Mines et de la Géologie 15, 105. 
Bio-Lokoto, A., Carbonnel, G., de Klasz, I., de Klasz, S., Lang, J., Salard-Cheboldaeff, M., 1998. Données nouvelles biochronologiques et paléoécologiques sur le bassin sédimentaire côtier du Bénin entre le Crétacé supérieur et l'éocène basal (Afrique de l'Ouest). Revue de Micropaléontologie 41, 29-57.

Bio oumarou, K.B., Kaki, C., d'Almeida, G.A.F., Tchokpon, G.C., Sokegbe, B.M.G., 2017. Pétrographie et environnements de dépôt des calcaires paléocènes du bassin sédimentaire côtier du Bénin. Afrique Science 13, 422-438.

Brochu, C.A., 1996. Closure of neurocentral sutures during crocodilian ontogeny: implications for maturity assessment in fossil archosaurs. Journal of Vertebrate Paleontology 16, 49-62.

Brochu, C.A., Bouaré, M.L., Sissoko, F., Roberts, E.M., O'Leary, M.A., 2002. A dyrosaurid crocodyliform braincase from Mali. Journal of Paleontology 76, 1060-1071.

Buffetaut, E., 1976, Une nouvelle définition de la famille des Dyrosauridae de Stefano, 1903 (Crocodylia, Mesosuchia) et ses conséquences: inclusion des genres Hyposaurus et Sokotosuchus dans les Dyrosauridae. Geobios 9, 333-336.

Buffetaut, E., Lauverjat, J., 1978. Un Crocodilien d'un type particulier dans le Cénomanien de Nazaré. Comptes Rendus Sommaire des Séances de la Société Géologique de France 1978, 7982.

Buffetaut, E., 1978. Les Dyrosauridae (Crocodylia, Mesosuchia) des phosphates de l'Eocène inférieur de Tunisie: Dyrosaurus, Rhabdognathus, Phosphatosaurus: Géologie Méditerranéenne $5,237-256$.

Buffetaut, E., 1978a. Crocodilian remains from the Eocene of Pakistan: Neues Jahrbuch für Geologie und Paläontologie Abhandlungen 156, 262-283. 
Buffetaut, E. 1978b. A dyrosaurid (Crocodylia, Mesosuchia) from the Upper Eocene of Burma. Neues Jahrbuch für Geologie und Paläontologie, Abhandlungen 1978, 273-281.

Buffetaut, E., 1979. Sokotosuchus ianwilsoni and the evolution of the Dyrosaurid crocodilians. Nigerian Field Monograph 1, 31-41.

Buffetaut, E., 1979. Présence du Crocodilien Phosphatosaurus (Mesosuchia, Dyrosauridae) dans le Paléocène du Niger et du Mali. Paläontologische Zeitschrift 53, 323-333.

Buffetaut, E., 1980. Les crocodiliens paléogènes du Tilemsi (Mali), un apercu systématique; pp. 15-35 in Palaeovertebrata, Mémoire Jubilaire René Lavocat. Laboratoire de Paléontologie des Vertébrés de l'Ecole Pratique des Hautes Etudes, Montpellier, France.

Buffetaut, E., 1982. Radiation évolutive, paléoécologie et biogéographie des crocodiliens mésosuchiens. Mémoires de la Société Géologique de France 142, 1-88.

Buffetaut, E., 1983. Wounds on the jaw of an Eocene mesosuchian crocodilian as possible evidence for the antiquity of crocodilian intraspecific fighting behaviour. Paläontogische Zeitschrift 57, 143-145.

Buffetaut, E., Bussert, R., Brinkmann, W., 1990. A new non-marine vertebrate fauna in the Upper Cretaceous of northern Sudan. Berliner Geowissenschaftlische Abhandlungen 120, $183-$ 202.

Buffetaut, E., 1991. Fossil crocodilians from Tiupampa, (Santa Lucia Formation, Early Paleocene) Bolivia: a preliminary report. Fosiles y facies de Bolivia - Vol. I Vertebrados (R. Suarez-Soruco, ed.). Revista Técnica de YPFB 12: 541-544.

Callahan, W.R., Pellegrini, R., Schein, J.P., Maccauley, J.D., Parris, D.C., 2015. A nearly complete specimen of Hyposaurus rogersii (Crocodylomorpha, Dyrosauridae) from the Late 
Cretaceous-Early Paleogene of New Jersey. Journal of Vertebrate paleontology Abstracts 2015, 101.

Cappetta, 1972

Carbonnel G., Johnson A.K., 1989. Les ostracodes du Togo, taxonomie, biostratigraphie, apports dans l'organisation et l'évolution du bassin. Geobios 22, 409-443.

Carvalho, L.B. de., Azevedo S.A.K. de, 1997. Um crocodilo marinho (Mesosuchia: Dyrosauridae) no paleoceno da Bacia Pernambuco-Paraiba, Brasil. Ameghiniana 34, 532.

Churcher, C.S., Russell, D.A., 1992. Terrestrial vertebrates from Campanian strata in Wadi ElGedid (Kharga and Dahkleh Oases), Western Desert of Egypt. Journal of Vertebrate Paleontology S12, 23A.

Cidade, G.M., Fortier, D., Hsiou, A.S., 2019. The crocodylomorph fauna of the Cenozoic of South America and its evolutionary history: a review. Journal of South American Earth Sciences $90,392-411$.

Da Costa, Y.D., 2005. Biostratigraphie et paléogéographie du bassin côtier du Togo. Thèse de Doctorat Univ. Lomé, Togo, 1-405 (inédit).

Da Costa, P.Y.D., Johnson, A.K.C., Affaton, P., 2009. Biostratigraphy and geodynamic impact in the uppermost part of the northeastern coastal basin of Togo. Comptes Rendus Palevol 8, 511526.

Da Costa, P.Y.D., Affaton, P., Salaj, J., Johnson, A.K.C., Seddoh, K., 2013a. Biozonation des formations sédimentaires du bassin côtier du Togo (Afrique de l'Ouest). Revue Ivoirienne des Sciences et Technologies 21, 45-73. 
Da Costa, P.Y.D., Johnson, A.K.C., Affaton, P., 2013b. Les terrains paléozoïques et mésozoïques du bassin côtier togolais: Stratigraphie et Paléogéographie. Standard Scientific Research and Essays 1, 415-429.

Da Costa, P.Y.D., Medus, J., Flicoteaux, R., Salaj, J., Harmsmid, B., Affaton, P., Seddoh, K., 2013c. Biostratigraphie de la bordure septentrionale du bassin côtier togolais. Apport des données palynologiques et structurales. Rev CAMES 1, 6-20

d'Almeida, G.A.F., Kaki, C., Adeoye, J.A., 2016. Benin and Western Nigeria Offshore Basins: A Stratigraphic Nomenclature Comparison. International Journal of Geosciences 7, 177-188.

Damotte R., 1982. Ostracodes maestrichtiens et paléocènes du Togo. Cahiers de Micropaléontologie 2: 47-63.

de Stefano, G., 1903. Nuovi rettili degli strati a fosfato della Tunisia. Bollettino delle Società Geologica Italiana 22, 51-80.

de Souza, R.G., Hormanseder, B.M., Figueiredo, R.G., de Almeida Campos, D., 2019. Description of new dyrosaurid specimens from the Late Cretaceous-Early Paleogene of new jersey, United States, and comments on Hyposaurus systematics. Historical Biology 32, 1-17.

Denton, R.K.J., Bobie, J.L., Parris, D.C., 1997. The marine crocodilian Hyposaurus in North America. In Ancient marine reptiles. Edited by J.M. Callaway and E.L. Nicholls. Academic Press, San Diego and London, 375-397.

Elewa, A.M., 2002. Paleobiogeography of Maastrichtian to early Eocene ostracoda of North and West Africa and the Middle East. Micropaleontology 48, 391-398.

Gallo, V., Figueiredo, F.J.D., Carvalho, L.D., Azevedo, S.D., 2001. Vertebrate assemblage from the Maria Farinha Formation after the KT boundary. Neues Jahrbuch für Geologie und Paläontologie, Abhandlungen 219, 261-284. 
Guinot, G., Amoudji, Y.Z., Kassegne, K.E., Sarr, R., Johnson, A.K.C., Da Costa, P.Y.D., Hautier, L., 2020. Elasmobranchs from the upper Paleocene of Togo. Geobios, 58, 17-37.

Halstead, L.B., 1975. Sokotosuchus ianwilsoni n. g., g. sp., a new teleosaur crocodile from the Upper Cretaceous of Nigeria. Journal of Mining and Geology 11, 101-103.

Hastings, A.K., Bloch, J.I., Cadena, E.A., Jaramillo, C.A., 2010. A new small short-snouted dyrosaurid (Crocodylomorpha, Mesoeucrocodylia) from the Paleocene of northeastern Colombia. Journal of Vertebrate Paleontology 30, 139-162.

Hastings, A.K., Jonathan, I.B., Carlos, A.J., 2011. A new longirostrine dyrosaurid (Crocodylomorpha, Mesoeucrocodylia) from the Paleocene of north-eastern Colombia: Biogeographical and behavioural implications for New-World Dyrosayridae. Palaeontology 54, 1095-1116.

Hastings, A.K., Bloch, J.I., Jaramillo, C.A., 2015. A new blunt snouted dyrosaurid, Anthracosuchus balrogus gen. et sp. nov. (Crocodylomorpha, Mesoeucrocodylia), from the Palaeocene of Colombia. Historical Biology 27, 998-1020.

Hill, R.V., McCartney, J.A., Roberts, E.M., Bouaré, M.L., Sissoko, F., O'Leary, M.A., 2008. Dyrosaurid (Crocodyliformes: Mesoeucrocodylia) fossils from the Upper Cretaceous and Paleogene of Mali: implications for phylogeny and survivorship across the K/T Boundary. American Museum Novitiates 3631, 15-17.

Johnson, A.K.C., 1987. Le bassin côtier à phosphates du Togo (Maestrichtien-Eocène). Thèse de doctorat, université de Bourgogne (France) et Université du Bénin (Togo). 360p. 
Johnson, A.K.C., Rat, P., Lang, J., 2000. Le bassin sédimentaire à phosphates du Togo (Maastrichtien-Eocène): stratigraphie, environnements et évolution. Journal of African Earth Sciences 30, 183-200.

Johnson, A.K., Da Costa, Y.D., 2008. Le Passage Paléocène-Eocène dans les bassins sédimentaires côtiers du golfe Du Benin: Togo, Benin et Nigeria. Revue Ivoirienne des Sciences et Technologies 11, 193-205.

Jouve, S., Schwarz, D., 2004. Congosaurus bequaerti, a Paleocene dyrosaurid (Crocodyliformes; Mesoeucrocodylia) from Landana (Angola). Bulletin de 1'Institut Royal des Sciences Naturelles de Belgique, Sciences de la Terre 74, 129-146.

Jouve, S., 2005. A new description of Dyrosaurus phosphaticus (Thomas, 1893) (Mesoeucrocodylia: Dyrosauridae) from the Lower Eocene of North Africa. Canadian Journal of Earth Sciences 42, 323-337.

Jouve, S., Bouya, B., Amaghzaz, M., 2005a. A short-snouted dyrosaurid (Crocodyliformes, Mesoeucrocodylia) from the Palaeocene of Morocco. Palaeontology 48, 359-369.

Jouve, S., Iarochène, M., Bouya, B., Amaghzaz, M., 2005b. A new crocodyliform dyrosaurid from the Palaeocene of Morocco and a phylogenetic analysis of Dyrosauridae. Acta Palaeontologica Polonica 50, 581-594.

Jouve, S., Iarochène, M., Bouya, B., Amaghzaz, M., 2006. A new species of Dyrosaurus (Crocodylomorpha, Dyrosauridae) from the early Eocene of Morocco: phylogenetic implications. Zoological Journal of the Linnean Society 148, 603-656. 
Jouve, S., 2007. Taxonomic revision of the dyrosaurid assemblage (Crocodyliformes: Mesoeucrocodylia) from the Paleocene of the Iullemmeden Basin, West Africa. Journal of Paleontology 81, 163-175.

Jouve, S., Bouya, B., and Amaghzaz, M., 2008. A long-snouted dyrosaurid (Crocodyliformes, Mesoeucrocodylia) from the Paleocene of Morocco: phylogenetic and palaoebiogeographic implications. Palaeontology 51, 281-294.

Jouve, S., Khalloufi, B., Zouhri, S. 2019. Longirostrine crocodylians from the Bartonian of Morocco and the Paleogene climatic and sea level oscillations in the peri-Tethys area. Journal of Vertebrate Paleontology e1617723.

Jouve, S., Jalil, N.E. 2020. Paleocene Resurrection of a Crocodylomorph Taxon: Biotic Crises, Climatic and Sea Level Fluctuations. Gondwana Research 85: 1-18. https://doi.org/10.1016/j.gr.2020.03.010.

Jouve, S., Muizon, C. de., Cespedes-Paz, R. Sossa-Soruco, V., Knoll, S. 2020. The Longirostrine Crocodyliforms from Bolivia and Their Evolution through the Cretaceous-Palaeogene Boundary. Zoological Journal of the Linnean Society, https://doi.org/10.1093/zoolinnean/zlaa081.

Kaki, C., d'Almeida, G.A.F., et Bio Oumarou B.K., 2016. Particularités sédimentologiques et géochimiques des calcaires d'Onigbolo (Sud-est du Benin), European Journal of Scientific Research 137, 182-196.

Khosla, A., Sertich, J.J., Prasad, G.V., Verma, O., 2009. Dyrosaurid remains from the intertrappean beds of India and the Late Cretaceous distribution of Dyrosauridae. Journal of Vertebrate Paleontology 29,1321-1326. 
Kjemperud, A., Agbesinyale, W., Agdestein, T., Gustafsson, C., Yüler, A., 1992. Tectonostratigraphic history of the Keta Basin, Ghana, with emphasis on tate erosional episodes. In: Géologie Africaine. Colloque Géologique, Libreville, pp. 55-69.

Kogbe, C.A., 1981. Cretaceous and Tertiary of the Iullemmeden Basin in Nigeria (West Africa). Cretaceous Research 2, 129-186.

Kogbe, C.A., Me'hes, K., 1986. Micropaleontology and biostratigraphy of the Coastal basins of West Africa. Journal of African Earth Sciences 5, 1-100.

Lamanna, M.C., Smith, J.B., Attia, Y.S., and Dodson, P., 2004. From dinosaurs to dyrosaurids (Crocodyliformes): removal of the post-Cenomanian (Late Cretaceous) record of Ornithischia from Africa: Journal of Vertebrate Paleontology 24, 764-768.

Langston, W., 1995, Dyrosaurs (Crocodilia, Mesosuchia) from the Paleocene Umm Himar Formation, Kingdom of Saudi Arabia, in Whitmore, F.C., and Madden, C.T., eds., Paleocene vertebrates from Jabal Umm Himar, Kingdom of Saudi Arabia: US Geological Survey Bulletin 2093, F1-F36.

Martin, J.E., 2013. Surviving a potentially lethal injury? Bite mark and associated trauma in the vertebra of a dyrosaurid crocodilian. Palaios $28,6-8$.

Martin, J.E., Amiot, R., Lécuyer, C., and Benton, M.J., 2014. Sea surface temperature contributes to marine crocodylomorph evolution: Nature Communications 5, 4658.

Martin, J.E., Sarr, R., Hautier, L., 2018. A dyrosaurid from the Paleocene of Senegal. Journal of Paleontology 93, 343-358.

Monciardini, C., Tchota K., Slansky M., Podevin, G.M.P., Le Nidre, Y.F,G., Châteauneuf, J.J., Castaing, C., Carbonel, G., Blondeau, A., Andreiff, P., 1986. Synthèse géologique du bassin 
côtier Crétacé Supérieur -Tertiaire du Togo. Recherche de tourbe, lignite, charbon et autres substances industrielles. Rapport BRGM 86 TGO. 60p.

Moody, R.T.J., Buffetaut, E., 1981. Notes on the systematics and palaeoecology of the crocodiles and turtles of the Metlaoui Phosphates (Eocene) of southern Tunisia. Tertiary Research 3, 125140.

Morsi, A.M.M., Speijer, R.P., Stassen, P., Steurbaut, E., 2011. Shallow marine ostracode turnover in response to environmental change during the Paleocene-Eocene thermal maximum in northwest Tunisia. Journal of African Earth Sciences 59, 243-268.

Parris, D.C., 1986. Biostratigraphy of the fossil crocodile Hyposaurus Owen from New Jersey. New Jersey State Museum 4, 1-16.

Pérez-García, A., Bardet, N., Fregenal-Martínez, M.A., Martín-Jiménez, M., Mocho, P., Narváez, I., Torices, A., Vullo, R. Ortega, F., 2020. Cenomanian vertebrates from Algora (central Spain): New data on the establishment of the European Upper Cretaceous continental faunas. Cretaceous Research115, 104566.

Petters, S.W., Olsson, R.K., 1979. Planktonic Foraminifera from the Ewekoro Type Section (Paleocene) Nigeria. Micropaleontology 25, 206-213.

Piveteau, J., 1935. Le Dyrosaurus, crocodilien de l'Eocène inférieur de l'Afrique du Nord. Annales de Paléontologie 24, 51-71.

Piras, P., Delfino, M., Del Favero, L., Kotsakis, T., 2007. Phylogenetic position of the crocodylian Megadontosuchus arduini and tomistomine palaeobiogeography. Acta Palaeontologica Polonica, 52, 315-328. 
Prasad, G.V.R., Singh, V., 1991. Microvertebrates from the intertrappean beds of Rangareddi District, Andhra Pradesh and their biostratigraphic significance. Bulletin of the Indian Geologists Association 24, 1-20.

Rana, R.S., 1987. Dyrosaurid crocodile (Mesosuchia) from the infratrappean beds of Vikarabad, Hyderabad District, Andhra-Pradesh. Current Science 56, 532-534.

Salih, K.A.O., David, C., Robert, B., Nicole, K., Mutwakil, N., Johannes, M., 2016. First record of Hyposaurus (Dyrosauridae, Crocodyliformes) from the Upper Cretaceous Shendi Formation of Sudan. Journal of Vertebrate Paleontology 36, 1115408.

Sarr, R., 1998. Les ostracodes du Paléocène du Horst de Diass (Sénégal): biostratigraphie, systématique, paleoenvironnement. Revue de micropaléontologie 41, 151-174.

Sarr, R., Ndiaye, P.M., Niang-Diop, I., Gueye, M., 2000. Datation par les foraminiferes planctoniques d'une activite volcanique d'age lutetien a Toubab Dialow (Sénégal occidental). Bulletin de la Société géologique de France 171, 197-205.

Sarr, R., 2013. Ostracodes nouveaux du Paléogène du Sine Saloum (Sénégal, Afrique de l'Ouest): Biostratigraphie, paléoenvironnement. Revue de Paléobiologie 32, 569-588.

Sarr, R., 2015. Paleobiogeographic implications of Paleocene ostracods from Senegal and related West and North Africa basins. Revue de Micropaléontologie 58, 333-349.

Sertich, J., Manthi, F.K., Sampson, S., Loewen, M., Getty, M., 2006. Rift valley dinosaurs: a new Late Cretaceous vertebrate fauna from Kenya: Journal of Vertebrate Paleontology 26, 124A.

Schwarz, D., Frey, E., Martin, T., 2006. The postcranial skeleton of the hyposaurinae (Dyrosauridae; Crocodyliformes). Palaeontology 49, 695-718. 
Slansky, M., 1959. Contribution à l'étude géologique du bassin sédimentaire côtier du Dahomey et du Togo. Thèse de Doctorat ès Sciences, Nancy, 1 vol., 335 p.

Slansky, M., 1962. Contribution à l'étude du bassin sédimentaire du Dahomey et du Togo. Bureau de Recherche Géologique et Minière 11, 270 pp.

Souza, de R.G., Hörmanseder, B.M., Figueiredo, R.G., Almeida Campos, de, D., 2019. Description of new dyrosaurid specimens from the Late Cretaceous-Early Paleogene of New Jersey, United States, and comments on Hyposaurus systematics. Historical Biology 32, 13771393.

Storrs, G., 1986. A dyrosaurid crocodile (Crocodylia: Mesosuchia) from the Paleocene of Pakistan. Postilla 197, 1-16.

Stromer, E., 1910. Reptilien und Fischreste aus dem marinen Alttertiär von Südtogo (Westafrica). Monatsbericht der Deutschen Geologischen Gesellschaft 62, 478-507.

Syme, C.E., Salisbury, S.W., 2014. Patterns of aquatic decay and disarticulation in juvenile IndoPacific crocodiles (Crocodylus porosus), and implications for the taphonomic interpretation of fossil crocodyliform material. Palaeogeography, Palaeoclimatology, Palaeoecology 412: 108123.

Swinton W.E., 1930. On fossil Reptilia from Sokoto Province. Bulletin of the Geological Survey of Nigeria 13, 9-56.

Tessier, F., 1952. Contributions à la stratigraphie et à la paléontologie de la partie Ouest du Sénégal (Crétacé et Tertiaire). Gouvernement Général de l’Afrique Occidentale Française, Bulletin de la Direction des Mines 14, 7-569. 
Thévenin, A., 1911a. Le Dyrosaurus des phosphates de Tunisie: Annales de Paléontologie 7, 95108.

Thévenin, A., 1911b. Sur la persistance d'un type de Reptile secondaire au début du Tertiaire: Comptes Rendus Sommaires des Séances de la Société Géologique de France 12-13, 136-137.

Thomas, P., 1893. Description de quelques fossiles nouveaux ou critiques des terrains tertiaires et secondaires de la Tunisie recueillis en 1885 et 1886 par M. Philippe Thomas. Exploration scientifique de la Tunisie, 46 p., 3 pl., Paris.

Thomas, A.S., Hector, G.P., Thomas, M.L., 2016. Sabinosuchus coahuilensis, a new dyrosaurid crocodyliform from the Escndido Formation (Maastrichtian) of coahuila, Mexico, Journal of Vertebrate Paleontology 36, e1222586.

Troxell, E.L., 1925. Hyposaurus, a marine crocodilian. American Journal of Science. Series 59 , 489-514. 


\section{Tableaux}

$\begin{array}{ccccccc} & \text { a } & \text { b } & \text { c } & \text { d } & \text { e } & \text { pz }\left(^{\circ}\right) \\ \text { T9 } & 65 & 61 & 70 & 60 & 73 & 40 \\ \text { T10 } & 66 & 61 & 72 & - & - & - \\ \text { T11 } & 67 & 64 & 69 & 60 & 71 & 50 \\ \text { T12 } & 69 & - & - & 64 & 70 & - \\ \text { T13 } & 72 & 66 & - & 64 & 67 & 38 \\ \text { T14 } & 70 & 68 & 65 & 63 & 66 & 50 \\ \text { T15 } & 70 & 66 & 66 & 79 & 60 & 48 \\ \text { S1 } & 73 & 81 & 59 & 64 & 53 & - \\ \text { S2 } & - & - & - & - & - & - \\ \text { Cau1 } & 59 & 65 & 58 & 60 & - & -\end{array}$

Table 1. Measurements (in $\mathbf{m m}$ ) of postcranial features of specimen TAB8-3; a, anteroposterior length of centrum taken at mid-height; b, width of anterior margin of centrum; c, height of anterior margin of centrum; d, width of posterior margin of centrum; e, height of posterior margin of centrum; pz, angle of prezygapophysis to medial plane (after Schwarz et al., 2006).

Tableau 1. Mesures (en mm) de paramètres postcrâniens du spécimen TAB8-3 ; a, longueur antéropostérieure du centrum prise à mi-hauteur ; b, largeur de la marge antérieure du centrum ; c, hauteur de la marge antérieure du centrum ; d, largeur de la marge postérieure du centrum ; e, hauteur de la marge postérieure du centrum ; pz, angle des prézygapophyses par rapport au plan médial (d'après Schwarz et al., 2006). 


\section{Figure captions}

\section{Légendes des figures}

Fig. 1. Geographical and geological context of the dyrosaurid specimens presented in this study. A, Map of Africa with arrow pointing to the Maritime area of Togo and countries that previously yielded dyrosaurid specimens (see main text for references): 1, Algeria; 2, Senegal; 3, Cabinda, Angola; 4, Morocco; 5, Tunisia; 6, Egypt; 7, Sudan; 8, Ethiopia; 9, Kenya; 10, Niger; 11, Mali; 12, Nigeria; B, Geological map of the Togolese coastal sedimentary basin (région maritime) and sampled localities (indicated by white stars). Substrate legends: white $=$ continental terminal; green $=$ Maastrichtian; orange $=$ Paleocene; blue $=$ Eocene; yellow $=$ Oligo-Miocene; beige $=$ Quaternary. Adabion is Stromer's historical locality. C, Synthetic log of the sedimentological sections observed at WACEM and SCAN-TOGO quarries; D, the partial dyrosaurid skull (TAB8-1) during its extraction from the SCAN-TOGO quarry in June 2018; E, excavation of the articulated column (TAB8-3) from the SCAN-TOGO quarry in February 2019.

Fig. 1. Contexte géographique et géologique des spécimens de Dyrosauridés présentés dans cette étude. A, Carte de l'Afrique avec la flèche pointant le bassin sédimentaire côtier du Togo (région maritime) et les pays ayant précédemment fourni des spécimens de Dyrosauridés (voir texte principal pour les références) : 1, Algérie ; 2, Sénégal ; 3, Cabinda, Angola ; 4, Maroc ; 5, Tunisie ; 6, Egypte ; 7, Soudan ; 8, Ethiopie ; 9, Kenya ; 10, Niger ; 11, Mali ; 12, Nigeria ; B, Carte géologique du bassin sédimentaire du Togo (région maritime) et des localités échantillonnées (indiquée par des étoiles blanches). Légende du substrat : blanc $=$ continental terminal ; vert $=$ Maestrichtien $;$ orange $=$ Paléocène $;$ bleu $=$ Eocène $;$ jaune $=$ Oligo-Miocène $;$ beige $=$ Quaternaire. Adabion est la localité historique de Stromer. C, Log synthétique des sections sédimentaires observées dans les carrières de WACEM et de SCAN-TOGO ; D, le crâne partiel 
de dyrosauridé (TAB8-1) lors de son extraction dans la carrière de SCAN-TOGO en Juin 2018 ; E, fouille de la colonne vertébrale articulée (TAB8-3) provenant de la carrière de SCAN-TOGO en Février 2019.

Fig. 2. Dyrosauridae skull from the Thanetian of the Tabligbo area (TAB8-1) in A, dorsal, B, ventral and C, occipital views. Abbreviations: astf, anterior margin of supratemporal fenestra; boc, basioccipital; cqg, cranioquadrate groove; exo, exoccipital; fps, frontoparietal suture; fr, frontal; j, jugal; nc, neural canal; oc, occipital condyle; q, quadrate; qj, quadratojugal; fo, foramen; 1Eu, lateral Eustachian foramen; nc, neural canal; ltf, lower temporal fenestra; oc, occipital condyle ; ?po, postorbital;qjs, quadratojugal suture ; ?sq, squamosal; stf, supratemporal fenestra; tt, torus transiliens.

Fig. 2. Crâne de Dyrosauridae du Thanétien de la région de Tabligbo (TAB8-1) en vues A, dorsale $\mathrm{B}$, ventrale et $\mathrm{C}$, occipitale. Abréviations : astf, bord antéromédial de la fenêtre supratemporale ; boc, basioccipital ; cqg, conduit cranio-carré ; exo, exoccipital ; fps, suture frontopariétale ; fr, frontal ; jugal ; nc, canal neural ; oc, condyle occipital ; q, carré ; qj, quadratojugal ; fo, foramen ; 1Eu, lateral Eustachian foramen ; nc, canal neural ; ltf, fenêtre temporale inférieure ; oc, condyle occipital ; ?po, postorbital ; qjs, suture quadratojugale ; sq, squamosal ; stf, fenêtre supratemporale supérieure ; tt, torus transiliens.

Fig. 3. Isolated tooth (TAB8-2) from the Thanetian of the WACEM quarry, Tabligbo area, Togo in A, labial or lingual; B, distal views. La flèche blanche indique la carène mésiodistale. 
Fig. 3. Dent isolée (TAB8-2) provenant du Thanétien de la carrière de WACEM, région de Tabligbo, Togo en vues A, labiale ou linguale ; B, distale. The white arrow indicates the mesiodistal carina.

Fig. 4. An isolated left calcaneum (TAB8-4) from the Thanetian of the WACEM quarry, Tabligbo area, Togo. A, medial; B, anterior; C, lateral; D, posterior; E, dorsal and F, ventral views. Abbreviations: ab, anterior ball; cs, calcaneal socket; lvc, lateroventral channel; mc, medial channel; mf, medial flange; ptu, posterior tuber.

Fig. 4. Calcanéum isolé (TAB8-4) provenant du Thanétien de la carrière WACEM, région de Tabligbo, Togo. Vues A, médiale ; B, antérieure ; C, latérale ; D, postérieure ; E, dorsale et F, ventrale. Abbréviations : ab, renflement antérieur ; cs, cavité calcanéale ; lvc, gouttière latéroventrale ; mc, gouttière médiale ; mf, rebord médiale ; ptu, tubérosité postérieure.

Fig. 5. Postcranial elements of a single dyrosaurid individual (TAB8-3) from the Thanetian of the SCAN-TOGO quarry, Tabligbo area, Togo. A, right lateral view of the articulated column. Selected elements including a thoracal vertebra from the anterior region in $\mathrm{B}$, anterior and $\mathrm{C}$, right lateral views; thoracal vertebra \#11 in $\mathrm{D}$, ventral; $\mathrm{E}$, right lateral and $\mathrm{F}$, anterior views; sacral vertebra \#1 in $\mathrm{G}$, posterior view, and $\mathrm{H}$, lateral view including displaced sacral rib in dorsal view; I, close up of second sacral rib in right lateral view with inferred outline of its posterior process; J, close up of first sacral rib in right lateral view; caudal vertebra \#1 in $\mathrm{K}$, posterior and L, right lateral views; a caudal vertebra from a more posterior region of the column in $\mathrm{M}$, anterior, $\mathrm{N}$, ventral and $\mathrm{O}$, right lateral views. $\mathrm{B}-\mathrm{O}$ are not to scale (for relative dimensions, refer 
to Fig. 4A and Table 1). Abbreviations: alpsr, anterolateral process of first sacral rib; cau, caudal vertebra; cf, chevron facet; hy, hypapophysis; prz, prezygapophysis; s, sacral vertebra; shf, shallow fossa ; $\mathrm{t}$, thoracal vertebra; tp, transverse process.

Fig. 5. Eléments post-crâniens d'un seul individu de Dyrosauridae provenant du Thanétien de la carrière de SCAN-TOGO, région de Tabligbo (TAB8-3). A, vue latérale droite de la colonne reconstituée ; Eléments choisis comprenant une vertèbre thoracale provenant de la région antérieure du tronc en vues B, antérieure et C, latérale droite ; vertèbre thoracale \#11 en vues D, ventrale ; E, latérale droite et F, antérieure ; vertèbre sacrée\#1 en vues $\mathrm{G}$, postérieure, et $H$, latérale incluant la côte sacrée associée déplacée en vue dorsale ; I, vue rapprochée de la seconde côte sacrée en vue latérale droite avec une reconstruction en pointillés de son processus postérieur ; J, détail de la première côte sacrée en vue latérale droite ; vertèbre caudale \#1 en vues $\mathrm{K}$, postérieure et $\mathrm{L}$, latérale droite ; une vertèbre caudale provenant d'une position plus postérieure de la colonne en vues $\mathrm{M}$, antérieure, $\mathrm{N}$, ventrale et $\mathrm{O}$, latérale droite. $\mathrm{B}-\mathrm{O}$ ne sont pas représentées à l'échelle (se référer à la Fig. 4A et à la table 1 pour les dimensions relatives). Abbréviations : alpsr, processus anterolateral de la première côte sacrée ; cau, vertèbre caudale ; cf, facette du chevron ; hy, hypapophyse ; prz, prezygapophyse ; s, vertèbre sacrée ; shf, fosse latérale; $t$, vertèbre thoracale ; tp, processus transverse.

Fig. 6. Isolated cervical vertebra (TAB8-7) from WACEM quarry showing the presence of encrusted invertebrates on its surface. A, posterior; B, right lateral and C, ventral views. Abbreviations: dia, diapophysis; hy, hypapophysis; para, parapophysis. 
Fig. 6. Vertèbre cervicale isolée (TAB8-7) provenant de la carrière WACEM et montrant la présence d'invertébrés encroûtés sur sa surface. Vues A, postérieure; B, latérale droite et C, ventrale. Abbréviations : dia, diapophyse ; hy, hypapophyse ; para, parapophyse.

Fig. 7. Isolated dyrosaurid specimens from the Thanetian of the WACEM quarry, Tabligbo area, Togo including a thoracal vertebra of a small individual (TAB8-9) in A, anterior and B, right lateral views; a caudal vertebra (TAB8-10) in C, anterior and D, right lateral views; E, a dorsal osteoderm (TAB8-11); F, another dorsal osteoderm (TAB8-12).

Fig. 7. Spécimens de Dyrosauridae retrouvés isolés et provenant du Thanétien de la carrière de WACEM, zone de Tabligbo, Togo incluant une vertèbre thoracale (TAB8-9) d'un petit individu en vues $\mathrm{A}$, antérieure et $\mathrm{B}$, latérale droite; une vertèbre caudale (TAB8-10) en vues $\mathrm{C}$, antérieure et $\mathrm{D}$, latérale droite; $\mathrm{E}$, un ostéoderme dorsal (TAB8-11) ; F, un second ostéoderme dorsal (TAB8-12). 

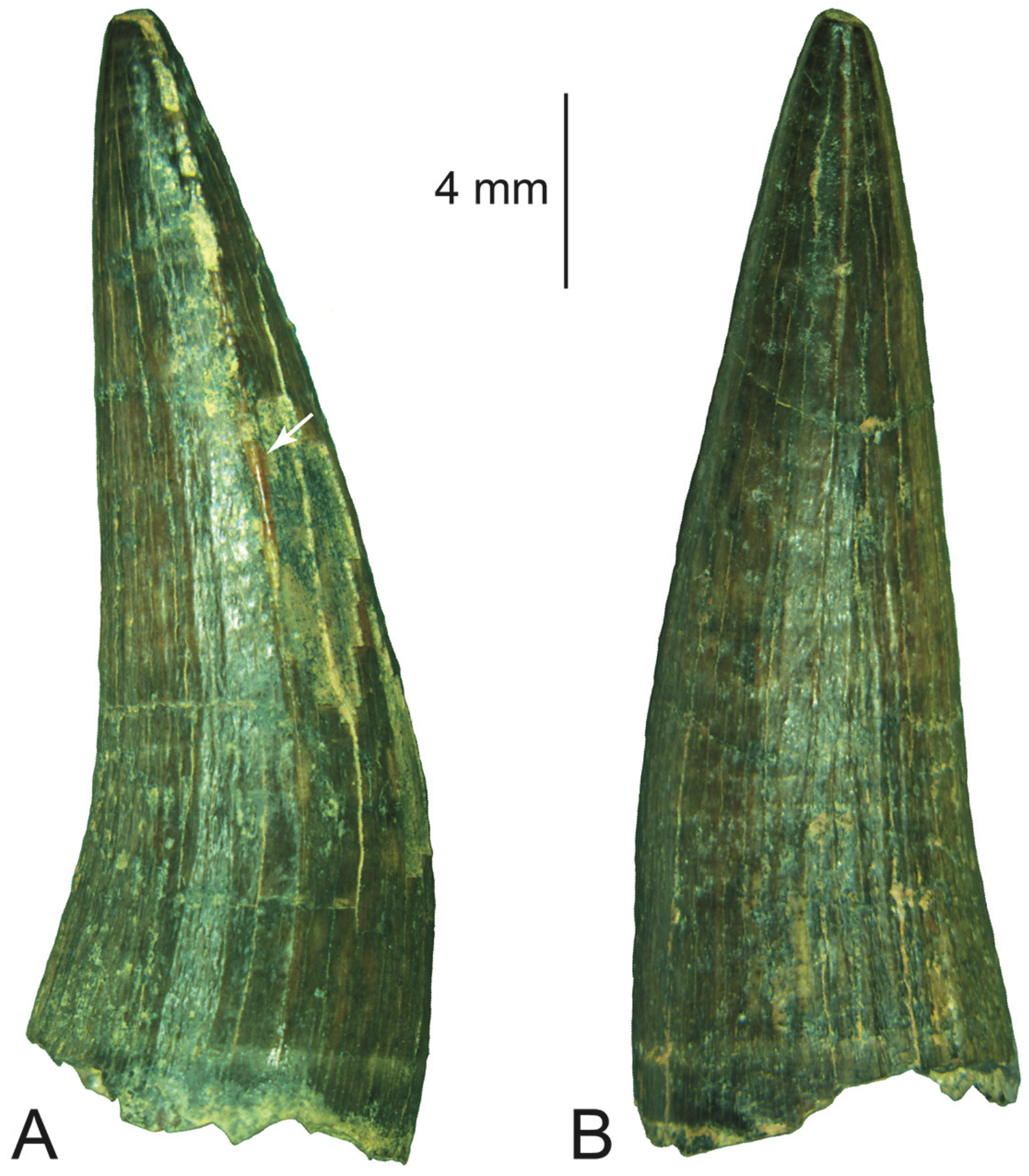

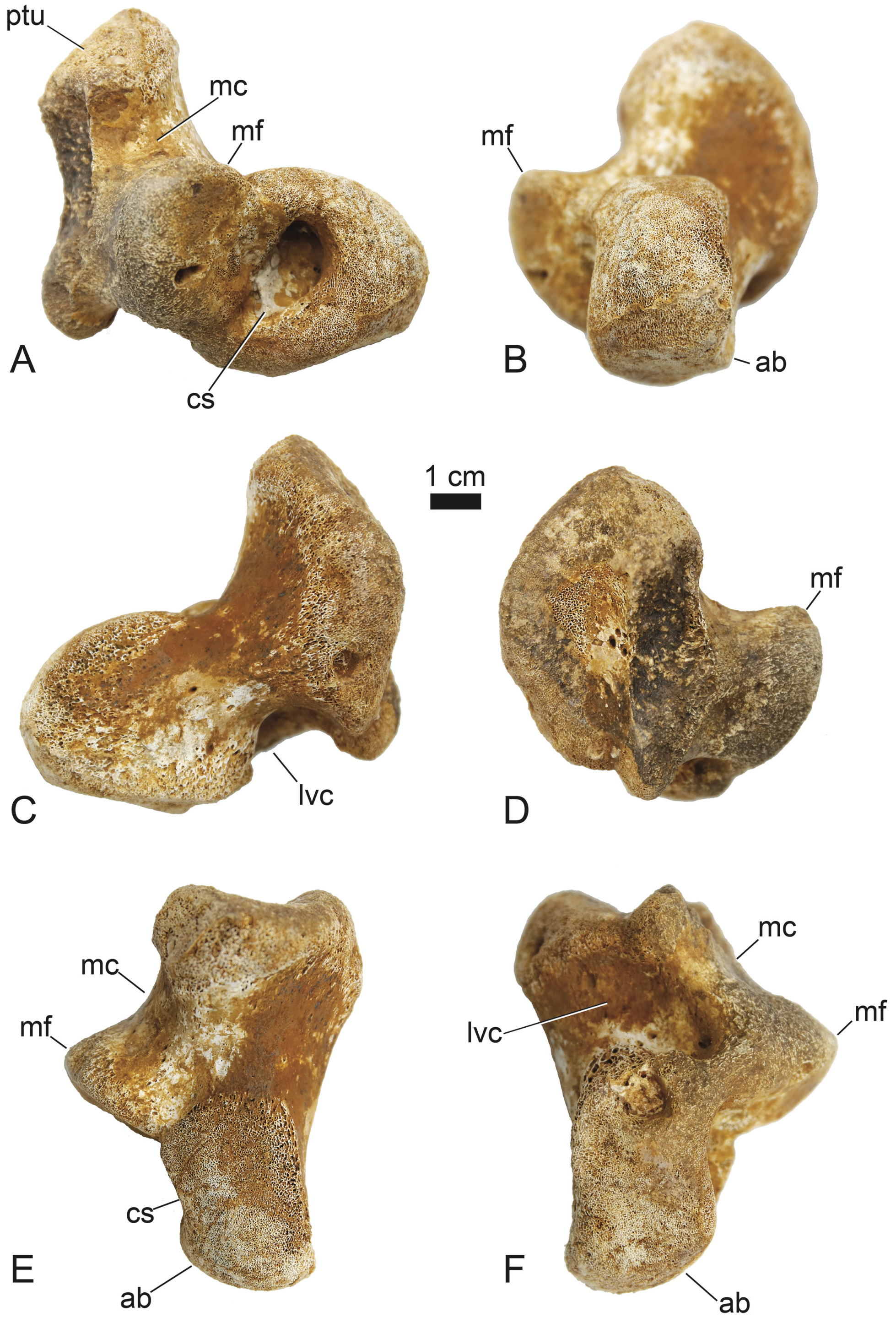

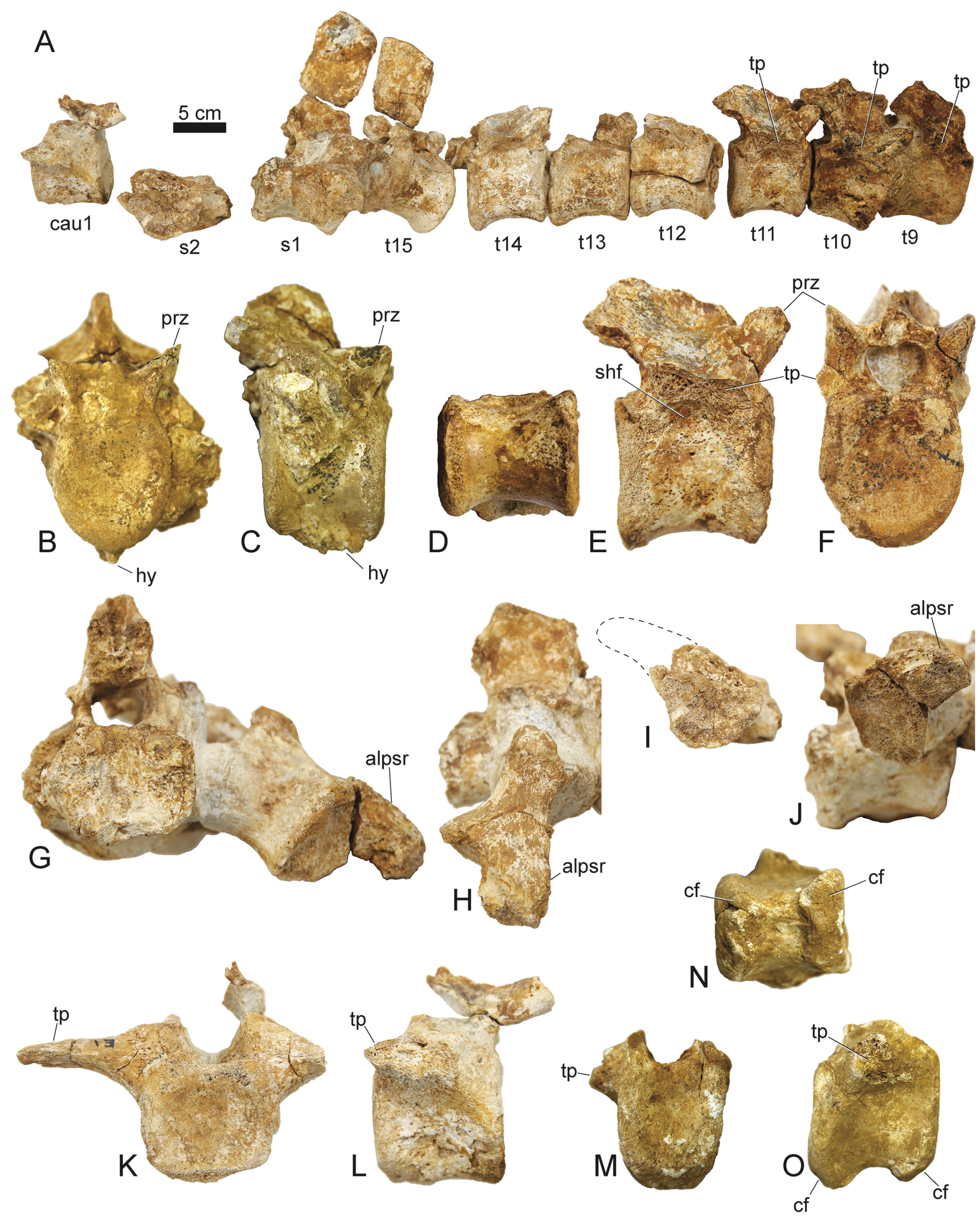

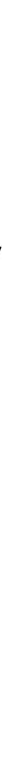


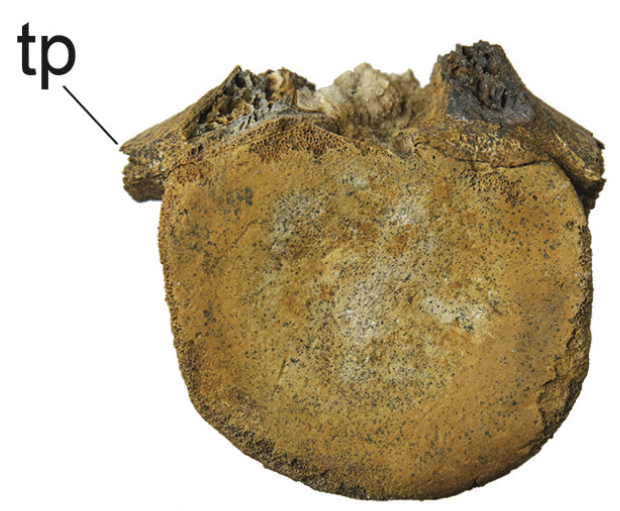

A

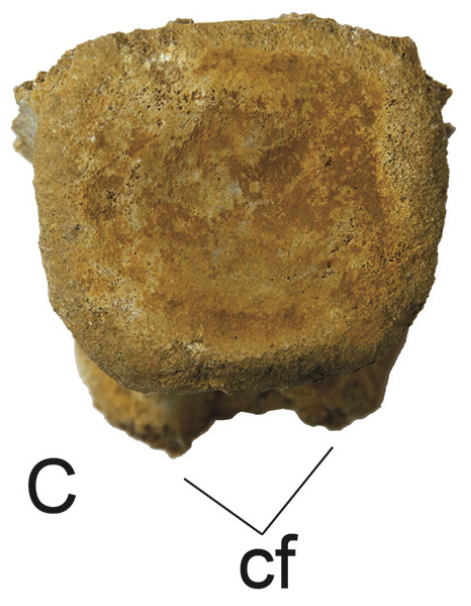

alp

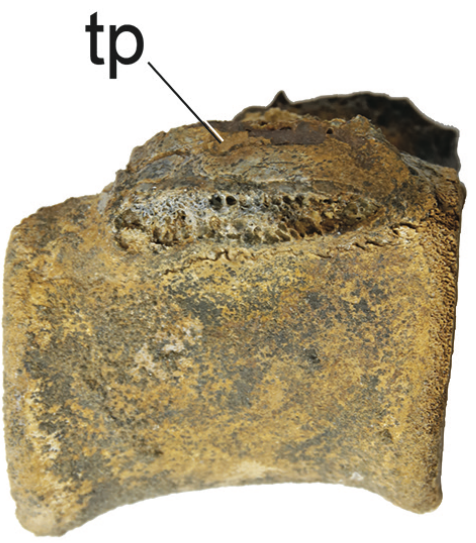

B

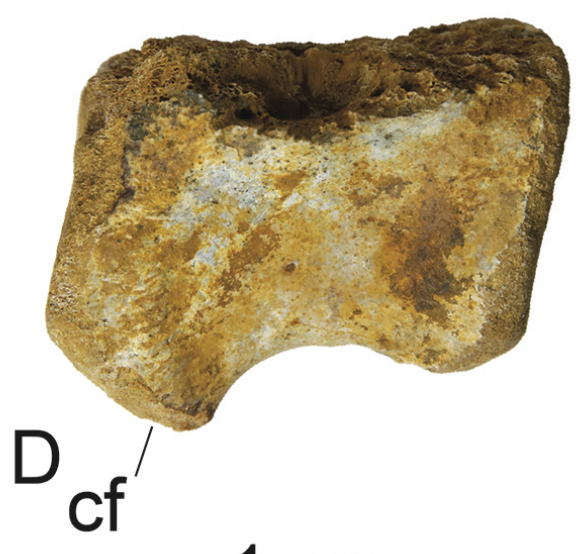

$1 \mathrm{~cm}$

E

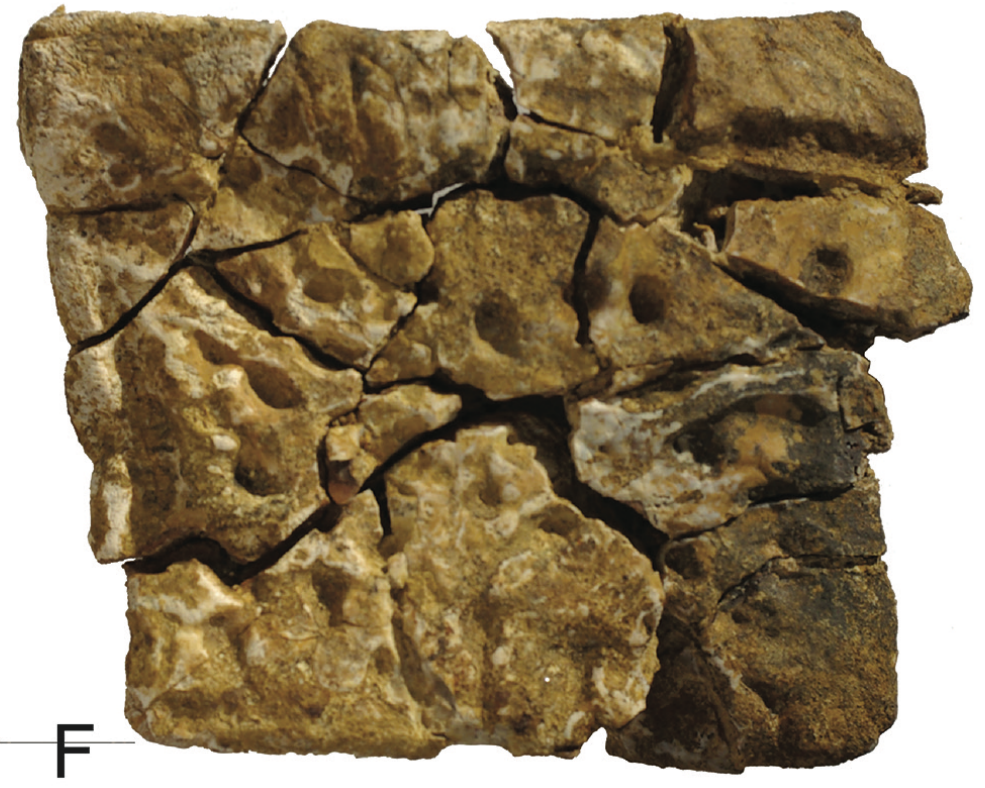

